\title{
Fluoressensiestudies van bindmiddels wat in kunswerke gebruik word
}

Outeurs:

Loreley Cairns,

Patricia Forbes

\section{Affiliasie:}

Departement Chemie, Universiteit van Pretoria

Privaatsak X20, Hatfield, 0028

Korresponderende outeur: L. Cairns

E-pos:

loreley.cairns@gmail.com

Hoe om hierdie artikel aan te haal:

Loreley Cairns, Patricia

Forbes, Fluoressensiestudies

van bindmiddels wat in

kunswerke gebruik word

Suid-Afrikaanse Tydskrif

vir Natuurwetenskap en

Tegnologie 38(1) (2019).

https://doi.org/10.36303/

SATNT.2019.38.1.760

\section{Kopiereg:}

(C) 2019. Authors

Licensee: Die Suid-

Afrikaanse Akademie vir

Wetenskap en Kuns.

Hierdie werk is onder

die Creative Commons

Attribution License

gelisensieer.

\begin{abstract}
Fluorescence studies on binding mediums used in paintings: Fluorescence studies are done on binding mediums specifically used in paintings. Research has shown that there is a distinct difference between major binder groups (drying oils and proteinaceous binders) but with no clear distinction between different binders in a group (linseed oil, poppyseed oil and walnut oil). Furthermore, research is being done on the influence that pigments will have on the fluorescence spectrum.
\end{abstract}

Die ontwikkeling van nie-afbrekende tegnieke vir die analise van kulturele erfenisvoorwerpe is krities om die visuele voorkoms van hierdie voorwerpe te behou. Dit is daarom belangrik dat geen monsterneming toegelaat word nie. Ultravioletfluoressensie word deur kunsbewaarders gebruik om areas van vorige restourasie aan te dui en is ook al tevore gebruik as 'n rumetode om bindmiddels volgens hulle fluoresserende kleure te identifiseer (Cosentino 2015). Bindmiddels bestaan soms uit meer as een fluoresseerder, en sal dus meer as een piek in 'n fluoressensiespektrum toon, waar net een kleur (die mees kenmerkende piek) met die blote oog waargeneem kan word. Fluoressensiespektroskopie is dus 'n waardevolle tegniek om verskillende bindmiddels te onderskei (Comelli et al 2008).

Verskillende bindmiddels kan uitgeken word deur die fluoressensiespektrum volgens die piekposisie en piekbreedte te ontleed. Die bindmiddels kan dan volgens soortgelyke fluoresseringseienskappe geklassifiseer word. Die eierbindmiddels (eiergeel, eierwit en heel eier) wat in Tempera skilderye voorkom, het 'n kenmerkende fluoresserende golflengte van $355 \mathrm{~nm}$ nadat dit met 'n $330 \mathrm{~nm}$ opwekkingslig bestraal is. Die gedroogte olies (lynsaad-, papawersaad- en okkerneutolie) het ' $n$ unieke fluoresserende golflengte van langer as $430 \mathrm{~nm}$. Bindmiddels word selde op hulle eie in 'n kunswerk getoets, omdat 'n kunswerk gewoonlik uit 'n mengsel van pigmente en bindmiddels bestaan. Verfmengsels is dus in die huidige studie met vier verskillende pigmente getoets om hul fluoresseringseienskappe te identifiseer, naamlik asuursteen, malagiet, geel oker en titanium-wit. Al hierdie pigmente is as niefluoresserende pigmente bevestig, maar het 'n fluoresserende sein aangedui wat toegeken kan word aan kristaloppervlaktes van die pigmente. Sommige verfmengsels het slegs die fluoressensiesespektrum van die pigmente getoon, terwyl ander geen spektrum getoon het nie.

Mikroskopiestudies het gewys dat hierdie verskynsels verduidelik kan word deur die manier waarop die bindmiddel die pigmente omvou. Verfmengsels waar die waargeneemde spektra dié van die bindmiddel was, is waar die bindmiddel die pigmentkristalle heeltemal bedek het. In teenstelling hiermee word die bindmiddel se fluoressensie nie waargeneem wanneer die kristalle bo die bindmiddel uitsteek nie.

Die malagiet het in al die bindmiddels (behalwe die droënde olies) die pigment se spektrum vertoon, terwyl geel oker en titanium-wit geen fluoressensie van die pigmente of bindmiddel getoon het nie. Asuursteen het die spektrum van die bindmiddel weerspieël waar die fluoressensiese piek met 10 tot $20 \mathrm{~nm}$ na 'n langer golflengte geskuif het. Hierdie tendense van die pigmente word vir alle bindmiddels waargeneem, buiten by die droënde olies wat 'n uitsondering is. Die spektra van droënde olies word nie drasties deur die pigmente geaffekteer nie, maar eerder deur die hoeveelheid vergeling wat die olie ondergaan het (De la Rie 1982). Malagiet het die meeste vergeling van die olie veroorsaak en dus die grootste verskuiwing van die pieke na langer golflengtes getoon. Die fluoressensie van verfmengsels word dus

Nota: 'n Seleksie van referaatopsommings: Studentesimposium in die Natuurwetenskappe, 25-26 Oktober 2018, SA Akademiegebou, Pretoria, Suid-Afrika. Gasredakteurs: Prof Rudi Pretorius (Departement Geografie, Universiteit van Suid-Afrika); Prof Chris Swanepoel (Departement Besluitkunde, Universiteit van Suid-Afrika); Me Andrea Lombard (Departement Geografie, Universiteit van Suid-Afrika) 
geaffekteer deur die soort pigmente wat teenwoordig is. Bindmiddels wat sterk fluoresseringsvermoëns het (soos die droënde olies), word minimaal deur die pigmente geaffekteer. Fluoressensiespektroskopie kan dus suksesvol onderskei tussen verskillende bindmiddels, hoewel die pigmente se effek op die fluoressensievermoë in ag geneem moet word.

\section{Literatuurverwysings}

Cosentino, A., 2015, 'Practical notes on ultraviolet technical photography for art examination', Conservar Património, 21, 53-62.

Comelli, D., Valentini, G., Nevin, A., Farina, A., Toniolo, L. \& Cubeddu, R., 2008, 'A portable UV-fluorescence multispectral imaging system for the analysis of painted surfaces', Review of Scientific Instruments, 79 (8), 086112

De la Rie, E. R., 1982, 'Fluorescence of paint and varnish layers (Part I-III)', Studies in Conservation, 27 (3), 102-108. 